\title{
SUBURBANISATION CHARACTERISTICS IN THE VICINITY OF RĪGA AFTER TRANSITION
}

\section{Suburbanizācijas procesa nevienmērīgās izpausmes Rīgas apkārtnē}

\author{
Toms Skadins \\ University of Latvia, Faculty of Geography and Earth Sciences \\ e-mail: toms.skadins@lu.lv
}

\begin{abstract}
After the fall of socialism, the most pronounced changes in the spatial structure of the population have been caused by suburbanisation. These changes have been especially notable since the end of the transition period. Therefore, the aim of this research was to characterise the features of suburbanisation in the vicinity of Riga after transition. Characteristics of suburbanisation were analysed based on the share of and number of people moving out of Rìga among all people moving. This was done for two periods - 2000 to 2011, and 2011 to 2019 - "the second of which has been less studied. The results showed that there were significant differences between the three share groups - a high proportion often went hand in hand with a large number of suburbanites. On the other hand, the differences between agglomeration and non-agglomeration areas were less clear-cut, as there were significant differences in the number of people previously living in Riga and its changes, while there were no significant differences in the share for the first stage and share changes.
\end{abstract}

Keywords: movers, suburbanisation intensity, Rĭga agglomeration

DOI: $10.22364 /$ fg. 18.3

\section{Introduction}

Since the end of the socialist period in Central and Eastern Europe, the most pronounced changes in the spatial structure of the population have been associated with suburbanisation in large urban regions (Gentile et al. 2012; Stanilov and Sykora 2014; Kurek et al. 2019). Conversely, it has become an important topic in many postsocialist states of the region. Previous studies have shown that changes are more pronounced in agglomerations of capital cities (Novak and Sykora 2007; Ahas et al. 2010; Novotny 2016). At the same time, research results indicate that development intensity is not uniform across all regions (Couch et al. 2007; Stanilov 2007; Egedy et al. 2017). That can also be applied to the areas surrounding Rīga (Krišjāne and Bērziṇš 2012).

Given the changes that have taken place and the current situation, it is important to pay attention to the driving forces behind them. Several studies have focused on suburbanisation (e.g. Kok and Kovacs, 1999 Tammaru et al. 2004; Hirt 2007) but very few studies have been conducted in recent years (Galka and Warych-Juras 2018; Ourednicek et al. 2019). Also, there seem to be an absence of papers that highlight the situation in areas just outside agglomerations. Consequently, the aim of this study is to characterise the features of suburbanisation in the vicinity of Riga after transition. Two research questions are put forward - What is the impact of suburbanisation in terms of the share and number of people moving (further on, mainly referred to as "movers"), 
both overall and for agglomeration and non-agglomeration territories separately? How did the situation differ between the two periods chosen for this study?

The particular time periods for this study were selected based on several aspects. First, the development of suburban areas and agglomerations after the collapse of socialism are divided into two stages: the transitional period of the 1990s and the development after the year 2000 (after the transition period). In the Baltic States, population growth has been much more pronounced in the new millennium (Leetmaa et al. 2009; Krišjāne et al. 2012). Second, the first period, from 2000 to 2011, includes both the most intensive suburbanisation (up to 2007) and the crisis period. The second period, meanwhile, includes the last stages of the crisis, the post-crisis phase and the most recent situation and has been less studied.

\section{Data and methods}

Central Statistical Bureau (CSB) data on population migration between territorial units (TUs), according to the borders existing in early 2019, was used to compare the situation on two dates. The following dates were used in this study: 01.01.2000-01.01.2011 and 01.01.2011-01.01.2019. This dataset was calculated using geospatial data, more specifically address point coordinates and the TU boundaries specified by the State Land Service. As a result, population changes which were the result of TU boundary changes were reduced. Another data set that was utilised was the cause of population changes in TUs (again, according to the borders existing in early 2019), comparing the situation on the two dates. From this data source, the total number of people who have changed their place of residence (within Latvia) was used. The same dates were used as in the case of internal migration data.

The study used descriptive analysis and non-parametric median tests to gain insights into the features of suburbanisation in the vicinity of Riga after transition. The former method was used to briefly describe the groups, while the latter was used to determine whether there were significant differences between groups. The intensity of suburbanisation was calculated for the two aforementioned periods. For this study it was defined as a share, calculated by comparing the number of inhabitants who moved from Riga to a particular place of residence sometime during a given period to all persons who were living in a different place of residence from where they had lived on the previous date. For the purposes of analysis, TUs were divided into three groups based on the total share of people moving, ranging from high (over 60\%) to low (less than 30\%). This distribution was chosen since it enabled easier comparison and analysis. The differences were looked at for the three groups (the number of movers), in agglomeration (defined by Skadiņš et al. 2019) and non-agglomeration areas (numbers and share), all of which were within $60 \mathrm{~km}$ of Rìga. This distance has been historically considered as the main sphere of the capital's influence (Krišjāne and Bērziņš 2009). Overall, 71 TUs were included in the analysis. 


\section{Results}

As can be seen in Figure 1, during the first period, the majority of TUs (30) had a high share of former Rịga residents. In absolute terms, though, there were considerable differences between them. Territories close (25 to $30 \mathrm{~km}$ ) to the capital had an absolute minimum of over 1000 movers from Rīga. Other TUs further away had (sometimes even noticeably) a lower influx of former Rìga residents. Nonetheless, this group tended to have more movers -24 out of 30 were above the median value of 215. Three non-agglomeration areas - Sejja and Skulte parishes and Vangaži town had a share of more than $60 \%$, with the number of movers above the median value.

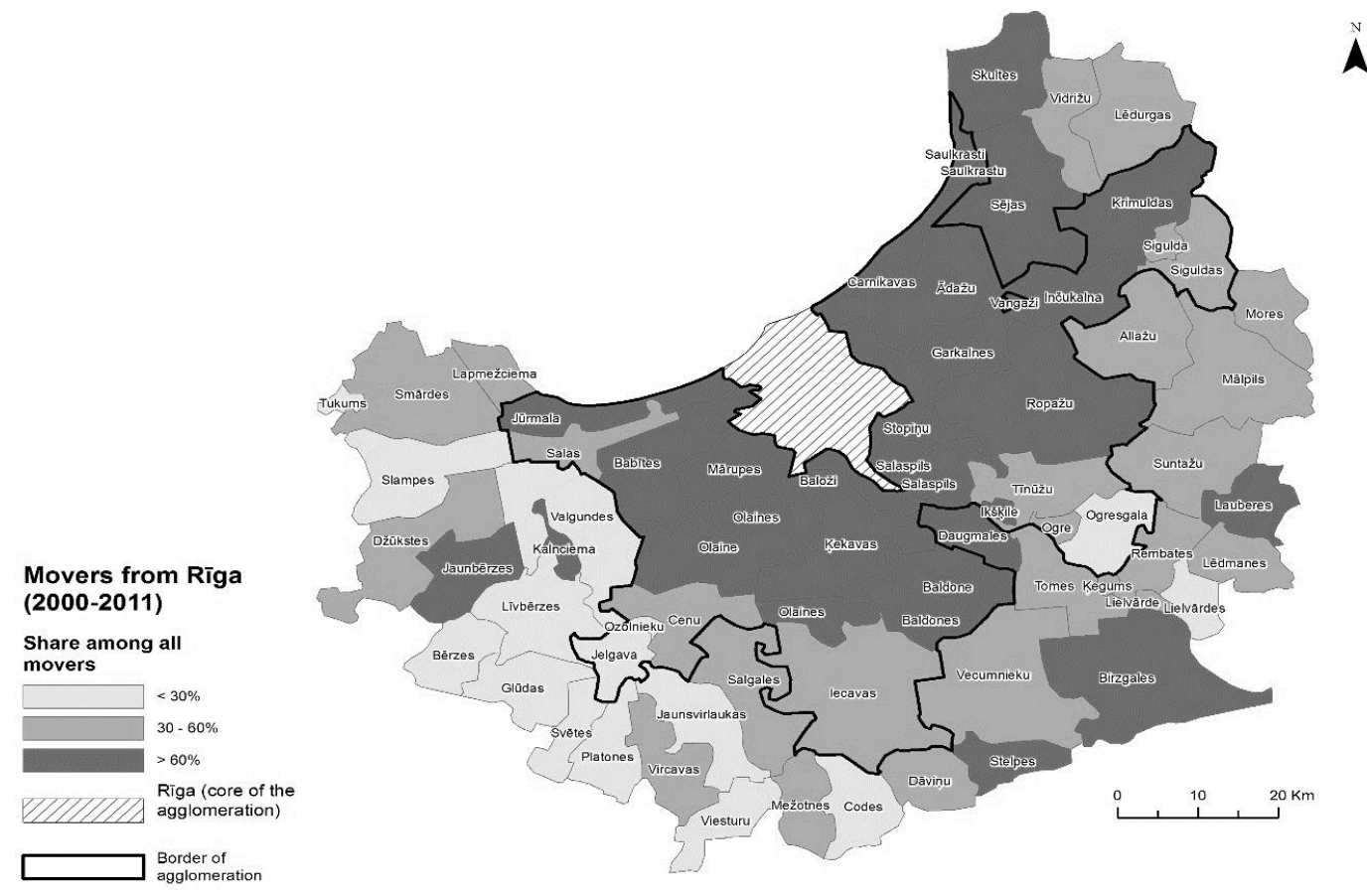

Figure 1. Share of movers from Rīga among all movers, from 2000-2011 (author's calculations, based on CSB 2019a, 2019b)

The medium-intensity group consisted of 25 TUs, six of which were part of the agglomeration. All of the agglomeration TUs, except Sala parish, saw an influx of movers larger than the median value. Another three TUs in non-agglomeration areas (the town of Lielvārde, and Smārde and Vecumnieki parishes) had a number of movers exceeding the median. Despite having a smaller share and generally lower numbers, movers from Rịga were still the prevalent group in nearly all areas.

Low intensity (below 30\%) and generally low numbers were characteristic of 16 TUs, most (13) of them being outside of the agglomeration, particularly those to the west and southwest of the agglomeration. This can be explained by the movement of inhabitants from Jelgava and Tukums to the nearby parishes. Jelgava, Tukums and Ozolnieki parish were the only ones in which the number of former Rīga residents was higher than the median value. TUs in this group either had a more pronounced connection with a TU other than Rīga or the flows were quite heterogenous. 
There were statistically significant differences (further on referred to as "significant differences") between the three share groups when it came to the number of movers (Asymp. Sig. < 0.01). As for the agglomeration/non-agglomeration divide, all but two agglomeration areas had a number of movers which was larger than the median value. Quite the contrary: just six areas outside of the agglomeration either matched or surpassed it. Simultaneously, 10 agglomeration TUs had a share below the median value (55.1\%), while 14 non-agglomeration TUs were above it. Consequently, the areas differed significantly for the former indicator (Asymp. Sig. $<0.01$ ) but did not for the latter (Asymp. Sig. $=0.06$ ).

In the next period, the number of TUs with a high share of suburbanites was smaller than before (Figure 2). In 23 TUs, at least $60 \%$ of all movers were former Rīga residents; 18 of those TUs belonged to the agglomeration. In this share group, only Daugmale and Krimulda parishes had less than the median value of 134 movers.

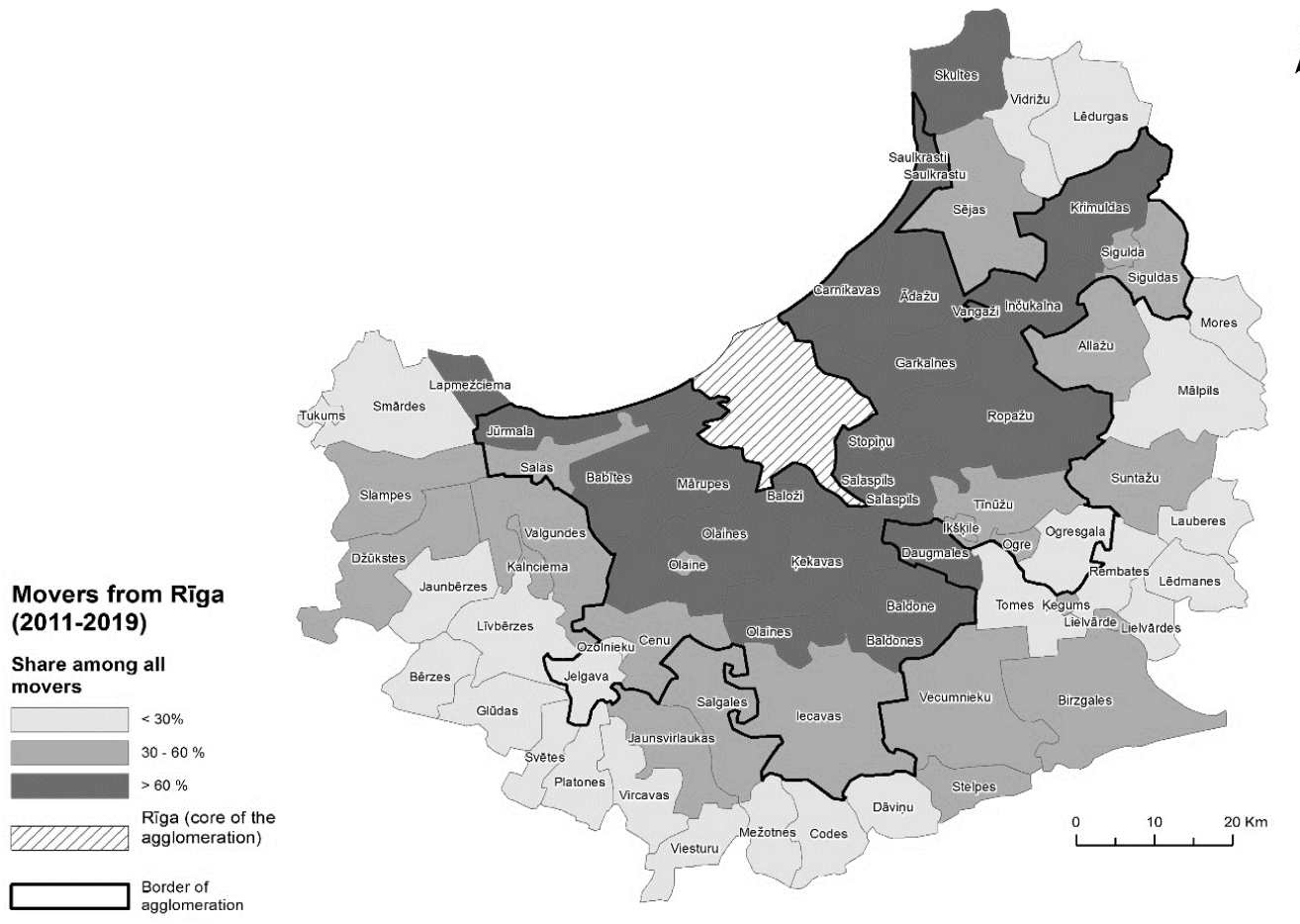

\section{A}

Figure 2. Share of movers from Rīga among all movers, from 2011-2019 (author's calculations, based on CSB 2019a, 2019b)

The size of the medium-intensity group decreased to 23 TUs; however, the number of agglomeration areas went up to nine. Still, most TUs (13) had a number of movers equal to or below the median. Of those that surpassed the median value, all but two were agglomeration TUs (the same as for the previous period). Once again, Sala parish was the lone agglomeration TU which did not surpass the median value.

The group which included the TUs with the lowest intensity increased to 25 members and still included the same three agglomeration areas. Four of the TUs had values above the median, with Smārde parish being a new addition to this group. The movement of former inhabitants from Jelgava and Tukums to nearby parishes 
continued to impact the situation. Several of the TUs which had a high share and low numbers in the previous period were now in the low group.

Again, there were statistically significant differences between the three share groups when it came to the number of movers (Asymp. Sig. < 0.01). This time agglomeration and non-agglomeration areas differed significantly for both the share and the number of movers. A total of 28 agglomeration TUs surpassed the median number of movers, while only seven non-agglomeration TUs did so. The distribution of groups based on share differed slightly: 26 above the median in agglomeration areas and nine for TUs outside of it.

As for the overall changes, they had various degrees of difference. The agglomeration areas saw a more significant drop, with just 5 of 31 TUs being above the median value (a decrease of 63 movers); among the non-agglomeration areas, 30 out of 40 had a value above the median. The median test indicated significant differences (Asymp. Sig. < 0.01). The situation with regard to share change was rather contrary - in this case, agglomeration TUs were less prone to experiencing notable changes. Conversely, 19 out of 31 TUs had a value larger than the median (a decrease of $1.8 \%$ ), with only 16 non-agglomeration TUs surpassing it. That was not the only difference, as the median test indicated that the disparities were not significant (Asymp. Sig. $=0.175$ ).

Only six out of the 71 TUs analysed had seen an increase in number of movers from the capital, with two of those being outside of the agglomeration. In these TUs, though, the increase was less sizeable than in the agglomeration TUs - except in Cenu parish, where the number of movers increased by 10. Close to half of all TUs saw a growth in their share of movers - 16 apiece in each group. Thus, despite most TUs either experiencing a negative (39) or a positive (five) change for both indicators, 25 TUs saw the number of movers go down and shares increase. This points to considerable changes in other internal migration flows. Typology based on the changes of indicators can be seen in Figure 3, and also includes a TU where the number of movers had not changed, while the share had increased. Territories outside the agglomeration were more likely to have a higher increase (with 10 out of 16 exceeding the median value of $3.5 \%$ ). Yet the median test indicated that the disparities were not significant (Asymp. Sig. $=0.157$ ).

One significant aspect, which was not related to share groups or the agglomeration/non-agglomeration divide, concerned changes in TUs bordering Rìga, in comparison to the rest of research area. Carnikava parish experienced the largest increase in the number of movers, while the other nine TUs saw a decrease. In seven of those cases it shrank by at least 1000 . The results of the median test indicated that the changes in these TUs were significantly different to those in all the other ones which saw a decrease (Asymp. Sig. < 0.05). Still, despite this change, all of them remained in the high share group. 


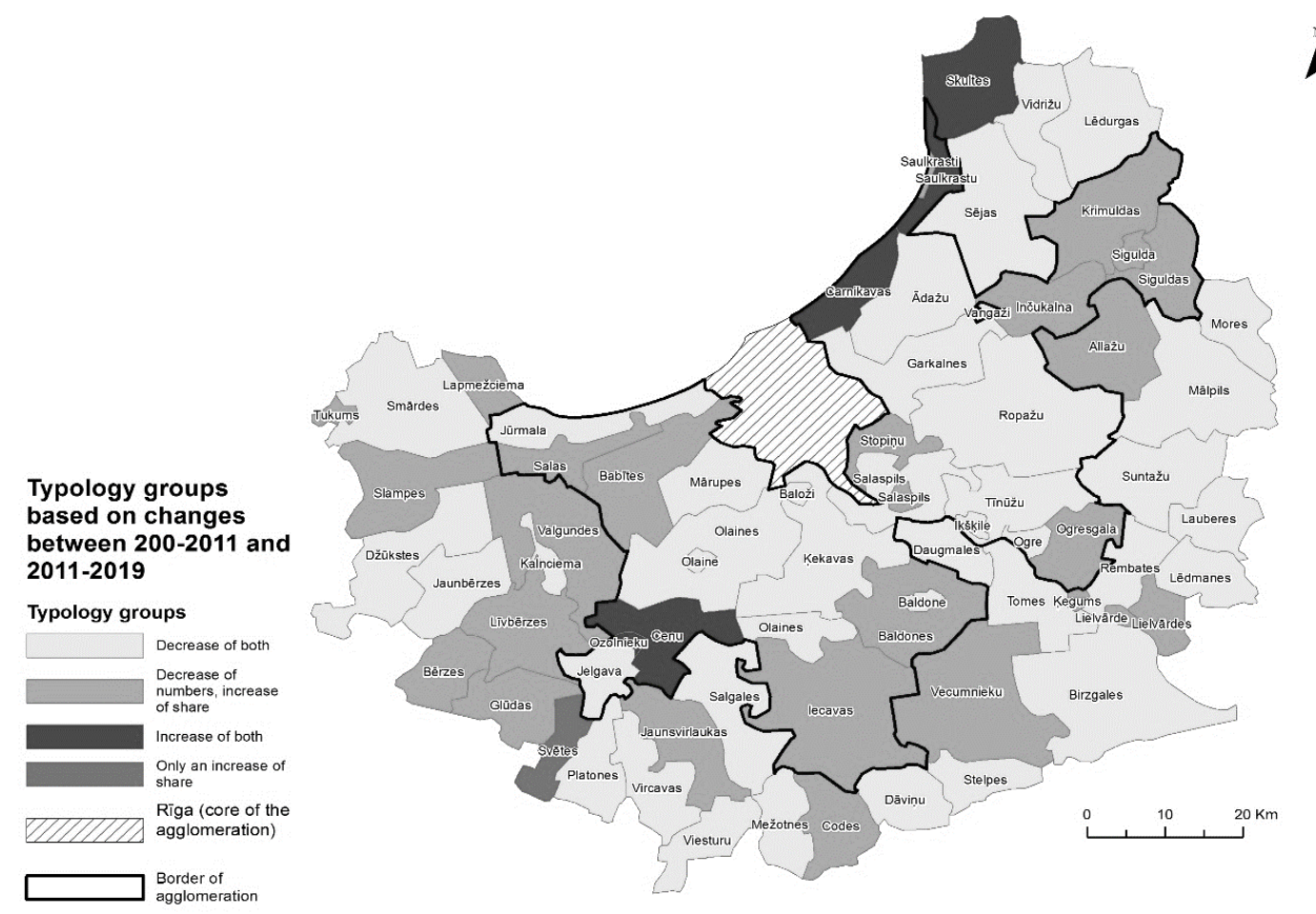

Figure 3. Typology groups based on changes between 2000-2011 and 2011-2019 (author's calculations, based on CSB 2019a, 2019b)

While the impact of suburbanites on the flows has been somewhat ambiguous, from a sheer numerical standpoint, suburbanisation has slowed down over time, with very few exceptions. This is contrary to developments in Czechia, where, after the financial crisis period, the intensity of in-migration increased in all agglomeration zones (Ourednicek et al. 2019). The situation in Rìga agglomeration is somewhat similar to the situation in the functional urban areas of Poland. There, during the postcrisis period the overall tendency has also been negative, although the decrease has been slight (Kurek et al. 2019). The reasons for such development could very well be related to those provided by Kurek et al. $(2019,161)$ : loans being more difficult to obtain or the impact of certain demographic processes.

\section{Conclusions}

The results highlight that the share and number of movers to agglomeration TUs tended to be greater than to non-agglomeration TUs, and test results showed that the significance increased over time. Also, a higher share of movers usually meant a significantly higher number of movers (i.e. above the median value).

Another aspect elucidated by the findings of the study was that percentage decrease of share were less common. The most significant decreases in numbers were found in the agglomeration and the decrease was statistically significant in nearly all TUs bordering the capital. Non-agglomeration territories, meanwhile, underwent an opposite change: a lesser numerical decrease and a larger drop in the share of people moving. Nevertheless, there were not significant differences in the share changes. 
These conclusions emphasise the necessity of focusing on the agglomeration alone. Another aspect that should be considered is the analysis of flows. This study focused on movers from Riga and while they tended to account for the majority of movers (especially in the agglomeration areas), a relatively large proportion of the flows are still unexplored. The share changes showed that shifts have clearly occurred for other groups too. Therefore, to develop a full picture of internal migration patterns to the Riga agglomeration, additional studies focusing on movers within the agglomeration and from the rest of Latvia will be needed.

\section{Acknowledgement}

This study was supported by National Research Program Project No. VPPIZM2018/1-0015.

\section{Kopsavilkums}

Pēc sociālisma perioda beigām visizteiktākās pārmainas iedzīvotāju telpiskajā struktūrā ir izraisījusi suburbanizācija. Šīs pārmaiņas ir bijušas īpaši izteiktas pēc pārejas perioda. Tāpēc šĩ pêtījuma mērḳis bija raksturot suburbanizācijas iezīmes Rīgas apkārtnē pēc pārejas perioda. Tās tika analizētas, ņemot vērā iepriekš Rīgā dzīvojošo iedzīvotāju īpatsvaru starp visiem dzīvesvietu mainījušajiem un to skaitu. Tas tika veikts diviem posmiem - no 2000. līdz 2011. gadam un no 2011. līdz 2019. gadam, kas ir mazāk pētîts posms. Rezultāti parāđīja, ka starp īpatsvaru grupām bija būtiskas atšḳirības - augsts īpatsvars bieži vien nozīmēja arī lielu dzīvesvietu mainījušo skaitu. Turpretī aglomerācijas un ārpus aglomerāciju teritoriju atškirīibas nebija tik nepārprotamas, jo saistībā ar iepriekš Rīgā dzīvojošo skaitu un tā pārmaiṇām pastāvēja būtiskas atšķirības, kamēr pirmā posma îpatsvaru un pārmaiņu ietvaros tādas nebija.

\section{References}

Ahas, R., Aasa, A., Slim, S. and Tiru, M. (2010). Daily rhythms of suburban commuters' movements in the Tallinn metropolitan area: case study with mobile positioning data. Transportation Research, 18C, 45-54.

CSP (2019a). LR Centrālās statistikas pārvaldes datu bāze - Iedzīvotāju iekšzemes migrācija starp statistiskajiem reǵioniem, republikas pilsētām, novadiem, novadu pilsētām, pagastiem, Rīgas apkaimēm (atbilstoši robežām 2019. gada sākumā) un blīvi apdzīvotām teritorijām salīdzinot stāvokli divos datumos. https://data.gov.lv/dati/lv/dataset/iekszemes-migracija (16.01 2020).

CSP (2019b). LR Centrālās statistikas pārvaldes datu bāze. RIG050. Pastāvīgo iedzīvotāju skaita izmaiņu iemesli statistiskajos reǵionos, republikas pilsētās, novados, novadu pilsētās, pagastos un Rīgas apkaimēs (atbilstoši robežām 2019. gada sākumā) salīdzinot stāvokli divos datumos. https://data1.csb.gov.lv/pxweb/lv/iedz/iedz__riga/RIG050.px (16.01 2020).

Egedy, T., Kovacs, Z. and Kondor, A.C. (2017). Metropolitan region building and territorial development in Budapest: the role of national policies. International Planning Studies, 22 (1), 14-29.

Couch, C. Leontidou, L. and Petschel-Held, G. (2007). Urban Sprawl in Europe: Landscapes, LandUse Change \& Policy. Oxford: Blackwell, 3-38.

Galka, J. and Warych-Juras, A. (2018). Suburbanization and migration in Polish metropolitan areas during political transition. Acta geographica Slovenica, 58 (2), 63-72.

Gentile, M., Tammaru, T. and van Kempen, R. (2012). Guest editorial: Heteropolitanization: social and spatial change in Central and East European cities. Cities, 29 (5), 291-349.

Hirt, S. (2007). Suburbanizing Sofia: Characteristics of post-socialist peri-urban change. Urban Geography, 28 (8), 755-780. 
Kok, H. and Kovacs, Z. (1999). The Process of Suburbanization in the Agglomeration of Budapest. Netherlands Journal of Housing and the Built Environment, 14 (2), 119-141.

Krišjāne, Z. and Bērziñ̌s, M. (2009). Commuting and the deconcentration of the post-socialist urban population: the case of the Riga agglomeration. Folia Geographica, 14, 56-74.

Krišjāne, Z. and Bērziṇš, M. (2012). Post-socialist urban trends: new patterns and motivations for migration in the suburban areas of Rīga, Latvia. Urban Studies, 49 (2), 289-306.

Krišjāne, Z., Bērziñš, M., Ivlevs, A. and Bauls, A. (2012). Who are the typical commuters in the postsocialist metropolis? The case of Riga, Latvia. Cities. 29 (5), 334-340.

Kurek, S., Wojtowicz, M. and Galka, J. (2019). Functional Urban Areas in Poland: Demographic Trends and Migration Patterns. Cham: Springer Nature.

Leetmaa, K., Tammaru, T. and Anniste, K. (2009). From priority-led to market-led suburbanization in a post-communist metropolis. Tijdschrift voor economische ne Sociale Geografie, 100 (4), 436-453.

Novak, J. and Sykora, L (2007). A city in motion: time-space activity and mobility patterns of suburban inhabitants and the structuration of the spatial organization of Prague metropolitan area. Geografiska Annaler B, 89 (2), 147-167.

Novotny, L. (2016). Urban development and migration processes in the urban region of Bratislava from the post-socialist transformation until the global economic crisis. Urban Geography, 37 (7), 10091029.

Ourednicek, M., Klsak, A. and Spackova, P. (2019). In between city and village: the development of spatial patterns of Czech suburbanisation 1997-2016. Demografie, 61 (4), 299-308.

Skadiņ̌š, T., Krūmiņš, J. and Bērziņšs, M. (2019). Delineation of an urban agglomeration: evidence from Riga, Latvia. Urban Development Issues, 62 (1), 39-46.

Stanilov, K. (2007). The Post-Socialist City: Urban Form and Space Transformations in Central and Eastern Europe after Socialism. New York: Springer Science \& Business Media, 185-187.

Sykora, L and, Stanilov, K. (2014). The challenge of postsocialist suburbanization. In: Stanilov, K., Sykora, L. (eds.). Urban Decentralization in Postsocialist Central and Eastern Europe. Oxford: WileyBlackwell., 1-23.

Tammaru, T., Kulu, H. and Kask, I. (2004). Urbanization, suburbanization and periurbanization in Estonia. Eurasian Geography and Economics, 45 (3), 159-176. 